\title{
New records of the alien longhorn beetle Neoclytus acuminatus (Coleoptera: Cerambycidae) in Romania
}

\author{
Lucian Hănceanu ${ }^{1}$, Maria-Magdalena Dascălu², Alexandru-Mihai Pintilioaie ${ }^{3}$
}

1 Faculty of Biology, Research Group in Invertebrate Diversity and Phylogenetics, "Alexandru Ioan Cuza" University, Bd. Carol I, nr. 11, 700506 Iași, Romania

2 CERNESIM (Integrated Center of Environmental Science Studies in the North East Region), Institute of Interdisciplinary Research, "Alexandru Ioan Cuza" University, Bd. Carol I, nr. 11, 700506 Iași, Romania

3 SC Biodiversity Research and Consulting SRL, Mircea cel Bătrân str, 700638 Iași, Romania

Corresponding author: Maria-Magdalena Dascălu (dascalumm@yahoo.com)

Received 12 January 2021 | Accepted 11 May 2021 | Published 30 June 2021

Citation: Hănceanu L, Dascălu M-M, Pintilioaie A-M (2021) New records of the alien longhorn beetle Neoclytus acuminatus (Coleoptera: Cerambycidae) in Romania. Travaux du Muséum National d'Histoire Naturelle "Grigore Antipa" 64(1): 81-88. https://doi.org/10.3897/travaux.64.e63053

\begin{abstract}
Neoclytus acuminatus is an alien longhorn beetle native to North America and currently established in Europe where it has a relatively wide distribution. Herein, its distribution in Romania is summarized based on new data accumulated since its first record fifteen years ago. Some aspects on its biology and morphology are discussed.
\end{abstract}

\section{Keywords}

Allochthonous species, citizen science, distribution, xylophagous.

About 20 species of alien longhorn beetles are known to have been introduced and established in Europe, some of them being present on the Old Continent at least since the middle $19^{\text {th }}$ century (Cocquempot and Lindelöw 2010; Leivadara et al. 2018; Sarto i Monteys and Torras i Tutusaus 2018; Cocquempot et al. 2019). With the intensification of global trade in the last decades, some 20 other alien cerambycid species were 
intercepted or recorded but not established (Cocquempot 2007; Cocquempot and Mifsud 2013).

Of all established alien species, several are members of the tribe Clytini: Chlorophorus annularis (Fabricius, 1787), Xylotrechus stebbingi Gahan, 1906, Xylotrechus chinensis (Chevrolat, 1852), and Neoclytus acuminatus (Fabricius, 1775). They all originate from Asia except the last one that originates from North America. Another Clytini, Xylotrechus grayii (White, 1855), which is a serious pest of Lonicera japonica Thunb. in Asia, is considered to have a small risk of establishment in Europe (Cocquempot 2007). Two more Asian species, Xylotrechus altaicus (Gebler, 1836) and Turanoclytus namanganensis (Heyden, 1885), were included on the EPPO A2 list of quarantine pests which require specific control measures (EPPO 2005a, b).

The genus Neoclytus Thomson, 1860 is confined to the Nearctic and Neotropical regions and includes almost 60 species and subspecies (Bezark 2016). Neoclytus acuminatus, also known as the redheaded ash borer, is native to North America and introduced to Puerto Rico, Cuba, and Argentina (Bezark 2016; Monné 2020). It was also introduced to Europe with the oldest records, as discussed by Pennerstorfer and Kriechbaum (2018), coming from the North Adriatic region: Rijeka (Küster 1851), Zadar (1891, in Jurc et al. 2016), and Istria (Reitter 1912). The collection of Ferdinand Jožef Schmidt proves that around the middle $19^{\text {th }}$ century this species was also present in Kranjsko (Carniola) (Brelih et al. 2006). The species naturalized itself in this region for a long time (Mikšić 1971; Mikšić and Georgijević 1973) and from here spread in many other adjacent European countries (Keszthelyi 2021). In Europe the species was recorded so far from Portugal (Madeira), France, Germany, Italy, Switzerland, Austria, Czechia, Hungary, Slovenia, Croatia, Montenegro, Serbia, Romania (Manci 2005; Cocquempot and Lindelöw 2010; Pennerstorfer and Kriechbaum 2018), UK (Buckle 1902; Duffy 1953), and Slovakia (Danilevsky 2020).

In Romania it was firstly recorded by Manci (2005) from Timișoara, in the western part of the country, based on a single specimen collected in 2002, hence the establishment of this species in our fauna was uncertain. It was reported a second time only recently based on specimens collected in 2015 from two forested sites, in the Iron Gates Natural Park (Brodie et al. 2019). According to newer records, N. acuminatus is currently widespread in Romania being found so far in 19 locations from 9 counties (Fig. 1). We included both observations based on collected specimens and pictures obtained via citizen science (from the Facebook group Insects of Romania and Europe, Nature Digital Object Repository, and BioLib databases). In chronological order of the first observation, they are as follows:

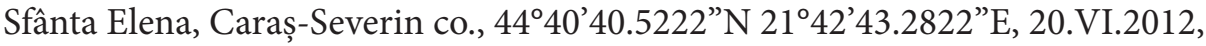


8.VIII.2014, on Robinia pseudoacacia L., leg. and coll. Cosmin Ovidiu Manci (at least


obs. and photo Adrian Spătăreanu and Ana Maria Matei (1 spec., not collected);

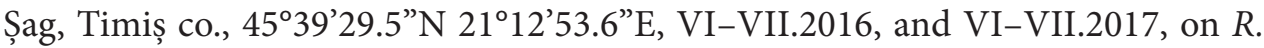
pseudoacacia logs and dead branches, obs. and photo Adorian Ardelean (few specs., 


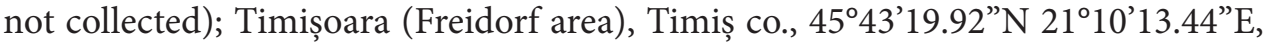
14.IX.2016, obs. and photo Adorian Ardelean (few specs., not collected); same locality and observer, VI-IX.2019, on logs of Carpinus sp. and Albizia julibrissin Durazz. (few specs., not collected); same locality and observer except $45^{\circ} 43^{\prime} 24.1^{\prime \prime} \mathrm{N} 21^{\circ} 10^{\prime} 32.5^{\prime \prime} \mathrm{E}$, 9.VI.2016 (few specs., not collected); same locality and observer, 5.VI.2018, on logs of A. julibrissin (few specs., not collected); Timișoara, Timiș co., $45^{\circ} 45^{\prime} 16.6^{\prime \prime} \mathrm{N}$ $21^{\circ} 16^{\prime} 46.2^{\prime \prime}$ E, 5.VIII.2019, on Salix sp., obs. and photo Danka Dragomir (2 specs. not

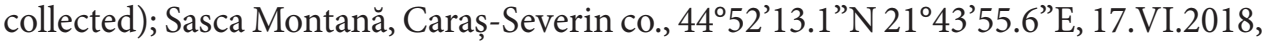
obs. and photo Adorian Ardelean (few specs., not collected); Scorțaru Vechi, Brăila co., $45^{\circ} 13^{\prime} 11.3^{\prime \prime} \mathrm{N} 27^{\circ} 44^{\prime} 49.6^{\prime \prime} \mathrm{E}$, 4.V.2019, on dead R. pseudoacacia branches, obs. and photo Andreea Gabriela Nechifor (1 spec., not collected); Dumbrăvița, Timiș

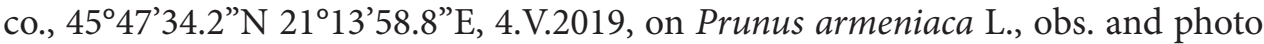
Danka Dragomir (2 specs. in copula, not collected); Băița, Bihor co., $46^{\circ} 28^{\prime} 53.84^{\prime \prime} \mathrm{N}$ $22^{\circ} 35^{\prime} 30.12^{\prime}$ E, 25.V.2019, edge of forest, leg. Bryan Marcus, coll. Cosmin Ovidiu Manci ( 7 specs.); Pârcovaci, Hârlău, Iași co., $47^{\circ} 26^{\prime} 46.2^{\prime \prime} \mathrm{N} 26^{\circ} 50^{\prime} 18.8^{\prime \prime} \mathrm{E}$, on wooden fence, leg. and coll. Lucian Hănceanu, 15.V.2020 (1 spec.) and 7.VI.2021 (32 specs.); same locality and collector except $47^{\circ} 26^{\prime} 58.3^{\prime \prime} \mathrm{N} 26^{\circ} 50^{\prime} 27.3^{\prime \prime} \mathrm{E}$, on logs, 26.IV.2021 (20 specs.) and 07.VI.2021 (50 specs.); Alba Iulia, Alba co., 46 $04^{\prime} 56.3^{\prime \prime} \mathrm{N} 23^{\circ} 33^{\prime} 47.9^{\prime \prime} \mathrm{E}$,

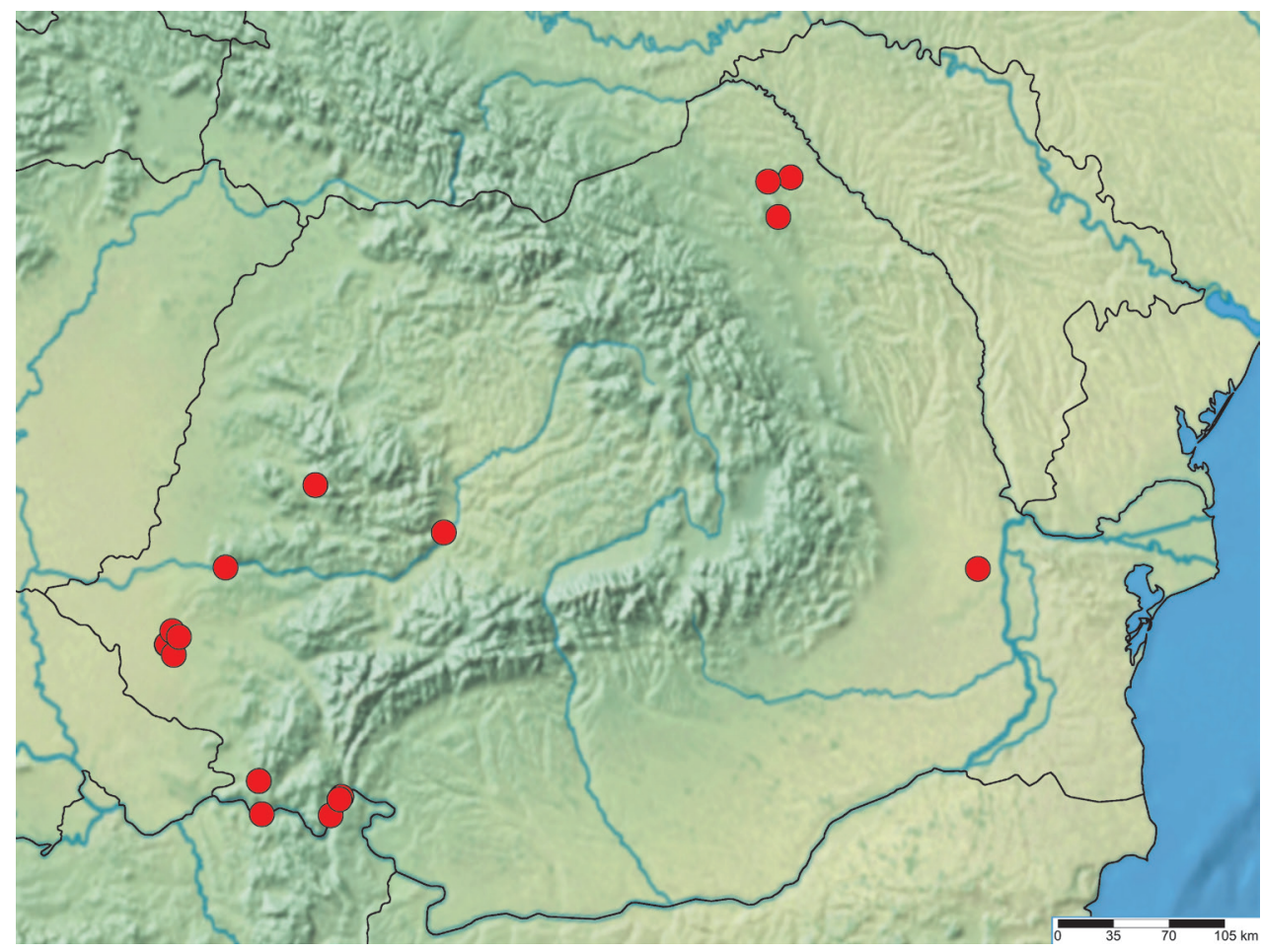

Figure 1. Distribution of Neoclytus acuminatus in Romania (sites in closed proximity are not displayed on the map). The map was generated with the software SimpleMappr (https://www.simplemappr.net). 
18.V.2020, obs. and photo Sebastian Marian Ianco (1 spec., not collected); Șoimoș, Arad co., 46 $06^{\prime} 13.0^{\prime \prime} \mathrm{N} 21^{\circ} 44^{\prime} 49.9^{\prime \prime} \mathrm{E}, 25 . \mathrm{V} .2020$, leg. and coll. Alexandru-Mihai

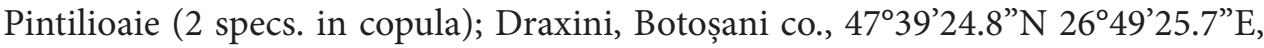
30.V.2020, on Quercus sp. and Ulmus sp. wood piles, obs. and photo Ionuț Nacu (1 spec., not collected).

Neoclytus acuminatus is a xilophagous species, polyphagous on a broad range of deciduous trees, shrubs, and vines, including fruit trees, ornamental shrubs, and grape vine (Craighead 1923; Bense 1995; Maier 2018). The records from Pinus and Taxodium were considered doubtful (Craighead 1923), however it was recently confirmed to develop in conifers like Abies, Chamaecyparis, Cryptomeria, Juniperus, Picea, and Tsuga (Maier 2009, 2018). It is believed that it was introduced to Europe with infested North American ash timber (Csóka and Kovács 1999; Jurc et al. 2016). In Europe and northern USA, the beetle takes one to two years to complete its life cycle (Bense 1995; Solomon 1995; Sama 2002), while in southern USA there may be two to three generations per year (Solomon 1995). Compared to many other species of Clytini that frequently visit flowers, adults of $N$. acuminatus apparently do not feed (Hanks and Wang 2017) and only occasionally visit blooming shrubs (Bense 1995). Otherwise, in sunny days they can be found on the host trees, logs or woodpiles, from April to August. The males produce an aggregation pheromone, that is why sometimes numerous individuals of both sexes aggregate on the host trees (Lacey et al. 2004). Tens of individuals (many of them in copula) were seen by the first author in Hârlău, near Pârcovaci forest, on logs deposited in yards for household heating. After mating, the females lay eggs in bark crevices and cracks, on trunks and branches. Larvae firstly develop under the bark then penetrate in the sapwood by digging tunnels filled with frass, but never feed in the heartwood (Solomon 1995). It overwinters as larva and pupation takes place in early spring in a pupal chamber close to the outer sapwood edge. The new generation of beetles emerges through round exit holes ( 2 to $5 \mathrm{~mm}$ in diameter) made in the bark with their mandibles (Solomon 1995).

Neoclytus acuminatus generally attacks weak, dying or recently dead trees but also newly planted trees and nursery stock. Freshly cut logs with bark still attached are also a source of infestation if these are not removed from the forest after cutting. The quality of the wood that will be processed into lumber is affected in case of infestations (Solomon 1995). In Romania it was found on the allochthonous trees R. pseudoacacia and A. julibrissin, on native trees (Carpinus sp., Quercus sp., Salix sp., Ulmus sp.), and on fruit trees (P. armeniaca). There are no quantitative data on the extent of the economic damage or potential ecological impact on the autochthonous fauna neither for Romania nor for other European countries (Cocquempot and Lindelöw 2010), although in its native range it is considered a pest (Sama 2002; Solomon 1995).

Clytini are known to be Batesian mimics that exhibit a coloration and a habitus resembling aculeate hymenopterans (Linsley 1959), and most likely the contrasting reddish-brown, yellow, and black colours of N. acuminatus are due to wasp mimicry. This beetle can be recognized by its slender, cylindrical, and elongate body with reddish brown coloration, long legs, short, distally thickened antennae, and four 

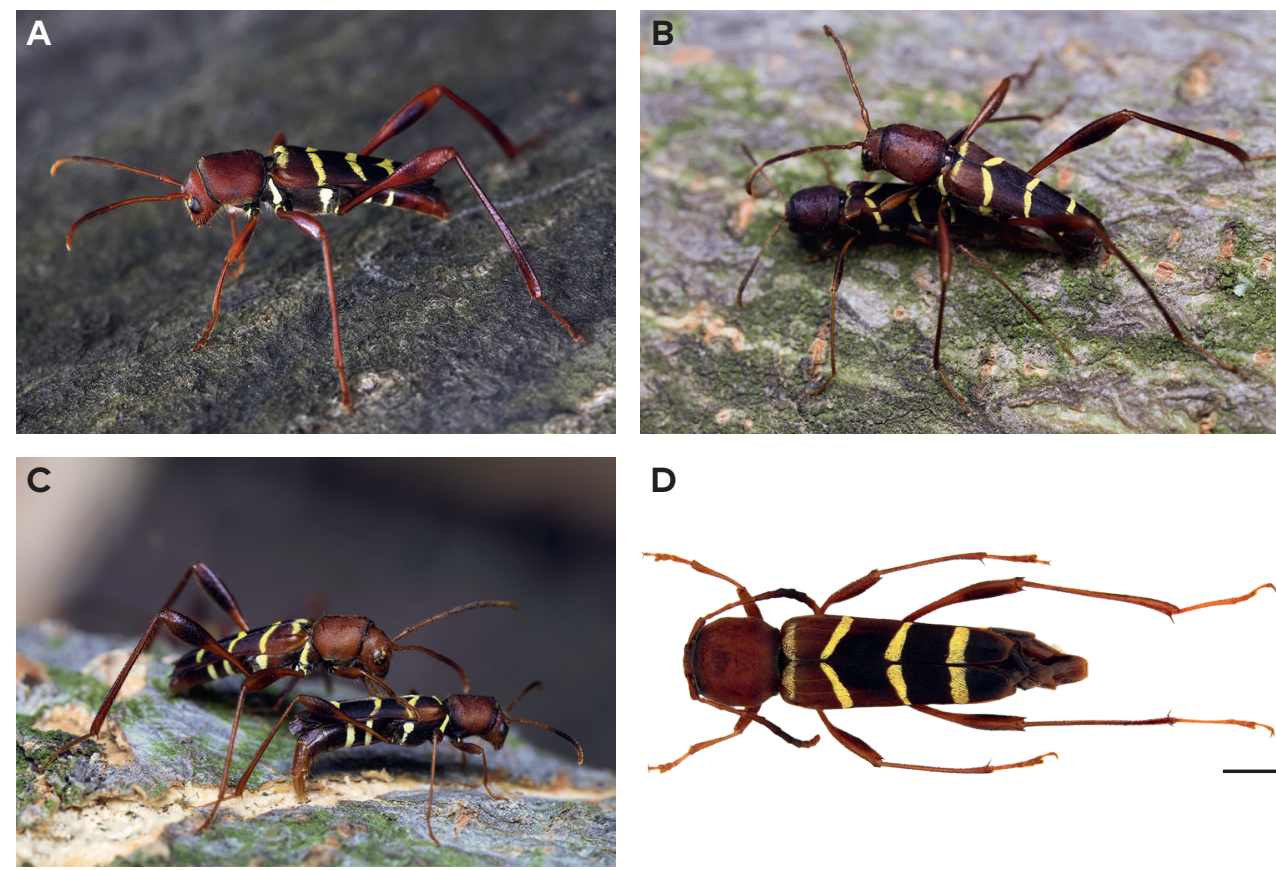

D

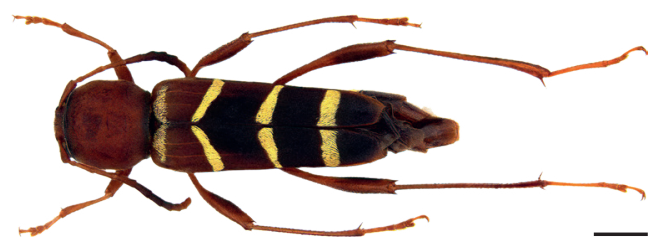

Figure 2. Neoclytus acuminatus. A-C adults in situ (photos by Adorian Ardelean, Timişoara); D habitus, specimen from Pârcovaci; scale bar: $2 \mathrm{~mm}$.

transverse yellow stripes on elytra (Fig. 2). An exhaustive description of the larva was made by Švácha and Danilevsky (1988); descriptions of larva and pupa may also be found in the monographs of Craighead (1923) and Duffy (1953).

\section{Acknowledgments}

We wish to thank Călin Hodor from Wildlife Management Consulting and Petrișor Galan from Biodiversity Research and Consulting for helping the third author with field campaigns. We are also thankful to Adorian Ardelean for the pictures of live specimens and distribution data, and to Sebastian Marian Ianco, Adrian Spătăreanu, Ana Maria Matei, Ionuț Nacu, Andreea Gabriela Nechifor, Cosmin Ovidiu Manci, and Danka Dragomir for distribution data. We are grateful to Jacek Kurzawa and Toni Koren for providing us some references and to the three reviewers for their useful comments that improved the manuscript. 


\section{References}

Bense U (1995) Longhorn Beetles. Illustrated Key to the Cerambycidae and Vesperidae of Europe. Margraf Verlag, Weikersheim, 512 pp. [in German and English]

Bezark LG (2016) Checklist of the Oxypeltidae, Vesperidae, Disteniidae and Cerambycidae (Coleoptera) of the Western Hemisphere. Online catalogue available at https://www.zin. ru/animalia/coleoptera/pdf/bezark_2016_western_hemisphaere_cerambycoidea.pdf

Brelih S, Drovenik B, Pirnat A (2006) Material for the Beetle Fauna (Coleoptera) of Slovenia $2^{\text {nd }}$ contribution: Polyphaga: Chrysomeloidea (= Phytophaga): Cerambycidae. Scopolia 58: 1-442. [in Slovenian and English]

Brodie BS, Popescu VD, Iosif R, Ciocanea C, Manolache S, Vanau G, Gavrilidis AA, Serafim

R, Rozylowicz L (2019) Non-lethal monitoring of longicorn beetle communities using generic pheromone lures and occupancy models. Ecological Indicators 101: 330-340. https://doi.org/10.1016/j.ecolind.2019.01.038

Buckle CW (1902) Entomological notes from Ulster. The Irish Naturalist 11(2): 40-44.

Cocquempot C (2007) Alien longhorned beetles (Coleoptera Cerambycidae): original interceptions and introductions in Europe, mainly in France, and notes about recently imported species. Redia 89: 35-50.

Cocquempot C, Lindelöw A (2010) Longhorn beetles (Coleoptera, Cerambycidae). Chapter 8.1. In: Roques A et al. (Eds) Alien terrestrial arthropods of Europe. BioRisk 4(1): 193-218. https://doi.org/10.3897/biorisk.4.56

Cocquempot C, Mifsud D (2013) First European interception of the brown fir longhorn beetle, Callidiellum villosulum (Fairmaire, 1900) (Coleoptera, Cerambycidae). Bulletin of the Entomological Society of Malta 6: 143-147.

Cocquempot C, Desbles F, Mouttet R, Valladares L (2019) Xylotrechus chinensis (Chevrolat, 1852), nouvelle espèce invasive pour la France métropolitaine (Coleoptera, Cerambycidae, Clytini). Bulletin de la Société entomologique de France 124(1): 27-32. https://doi. org/10.32475/bsef_2064. [in French]

Craighead FC (1923) North American cerambycid-larvae. A classification and the biology of North American cerambycid larvae. Dominion of Canada Department of Agriculture Bulletin No. 27 - New Series. Minister of Agriculture Ottawa, 150 pages, 44 plates, 8 text figures. https://doi.org/10.5962/bhl.title.63085

Csóka G, Kovács T (1999) Xylophagous insects. Forest Research Institute. Agroinform Kiadó, Budapest, 189 pp. [in Hungarian and English]

Danilevsky ML (2020) A check-list of longicorn beetles (Coleoptera, Cerambycoidea) of Europe. Updated: 2.03.2021. https://www.cerambycidae.net/europe.pdf (accessed at 1.06.2021)

Duffy EAJ (1953) A monograph of the immature stages of British and imported timber beetles (Cerambycidae). British Museum (Natural History), London, 350 pp.

EPPO, European and Mediterranean Plant Protection Organization (2005a) Data sheets on quarantine pests/Fiches informatives sur les organismes de quarantaine - Xylotrechus altaicus. Bulletin OEPP/EPPO Bulletin 35: 406-408. 
EPPO, European and Mediterranean Plant Protection Organization (2005b) Data sheets on quarantine pests/Fiches informatives sur les organismes de quarantaine - Xylotrechus namanganensis. Bulletin OEPP/EPPO Bulletin 35: 456-458.

Hanks LM, Wang Q (2017) Reproductive Biology of Cerambycids. In: Wang Q (Ed.) Cerambycidae of the World: Biology and Pest management. Boca Raton: CRC Press, Taylor \& Francis Group, 133-159.

Jurc M, Csóka G, Hrašovec B (2016) Potentially important insect pests of Celtis australis in Slovenia, Croatia and Hungary. Šumarski list 11-12: 577-588. https://doi.org/10.31298/ sl.140.11-12.5

Keszthelyi S (2021) Red-headed ash borer Neoclytus acuminatus acuminatus (Fabricius) (Coleoptera: Cerambycidae): the global distribution, current spreading and the seasonal activity depending on its different habitats. Journal of Plant Diseases and Protection, 1-13. https://doi.org/10.1007/s41348-021-00456-9

Küster HC (1851) Die Käfer Europa's. Nach der Natur beschrieben. Mit Beiträgen mehrerer Entomologen. Band 22. Bauer \& Raspe, Nürnberg, 100 pp. [in German]

Lacey ES, Ginzel MD, Millar JG, Hanks LM (2004) Male-produced aggregation pheromone of the cerambycid beetle Neoclytus acuminatus acuminatus. Journal of Chemical Ecology 30(8): 1493-1507. https://doi.org/10.1023/B:JOEC.0000042064.25363.42

Leivadara E, Leivadaras I, Vontas I, Trichas A, Simoglou K, Roditakis E, Avtzis DN (2018) First record of Xylotrechus chinensis (Coleoptera, Cerambycidae) in Greece and in the EPPO region. Bulletin OEPP/EPPO Bulletin 1-4. https://doi.org/10.1111/epp.12468

Linsley EG (1959) Mimetic form and coloration in the Cerambycidae (Coleoptera). Annals of the Entomological Society of America 52(2): 125-131. https://doi.org/10.1093/ aesa/52.2.125

Maier CT (2009) Distributional and host records of Cerambycidae (Coleoptera) associated with Cupressaceae in New England, New York, and New Jersey. Proceedings of the Entomological Society of Washington 111(2): 438-453. https://doi. org/10.4289/0013-8797-111.2.438

Maier CT (2018) Larval hosts of Cerambycidae (Coleoptera: Parandrinae, Prioninae, Lepturinae, Spondylidinae, Cerambycinae) in Connecticut and Nearby States. The Coleopterists Bulletin 72(3): 439-456. https://doi.org/10.1649/0010-065X-72.3.439

Manci CO (2005) Neoclytus acuminatus (Fabricius, 1775) gen şi specie nouă pentru fauna României (Coleoptera: Cerambycidae: Cerambycinae). Buletin de Informare Entomologică 16: 75-77. [in Romanian]

Mikšić R (1971) Katalog der Bockäffer (Cerambycidae) jugoslawiens (Insecta-Coleoptera) (posebno izdanje). Institut za Šumarstvo, Sarajevo, 70 pp. [in German]

Mikšić R, Georgijević E (1973) Cerambycidae Jugoslavije II dio. Djela XLV, Odjeljenje Prirodnih I Matematičkih Nauka 4. Akademija Nauka i Umjetnosti Bosne i Hercegovine, Sarajevo, 153 pp. [in Serbo-Croatian]

Monné MA (2020) Catalogue of the Cerambycidae (Coleoptera) of the Neotropical Region. Part I. Subfamily Cerambycinae. Online catalogue available at https://cerambycids.com/ catalog/Monne_2021_NeotropicalCat_part_I.pdf 
Pennerstorfer J, Kriechbaum M (2018) Erstnachweis von Neoclytus acuminatus (Fabricius, 1775) (Coleoptera: Cerambycidae) für Österreich. Beiträge zur Entomofaunistik 19: 140-143. [in German]

Reitter E (1912) Fauna Germanica. Die Käfer des Deutschen Reiches. Band 4. K. G. Lutz' Verlag, Stuttgart, 236 pp. + plates 129-152. [in German]

Sama G (2002) Atlas of the Cerambycidae of Europe and Mediterranean area. Vol 1: Northern,Western, Central and Eastern Europe. Nakladatelstvi Kabourek, Zlín, 173 pp. Sarto i Monteys V, Torras i Tutusaus G (2018) A new alien invasive longhorn beetle, Xylotrechus chinensis (Cerambycidae), is infesting mulberries in Catalonia (Spain). Insects 9(52): 1-16. https://doi.org/10.3390/insects9020052

Solomon JD (1995) Guide to insect borers in North American broadleaf trees and shrubs. Agriculture Handbook A-H 706. US Department of Agriculture, Forest Service, Washington DC, 735 pp.

Švácha P, Danilevsky ML (1988) Cerambycoid larvae of Europe and Soviet Union (Coleoptera, Cerambycoidea). Part II. Acta Universitatis Carolinae 31 [1987], 3-4: 121-284.

*** Insects of Romania and Europe group. https://www.facebook.com/groups/2551150 31327840 [Accessed on 10.11.2020]

$* \star \star$ Nature Digital Object Repository (mybiosis). https://kladia.info [Accessed on 6.11.2020]

*** BioLib Biological Library. https://www.biolib.cz/en/taxonimage/id185389/?taxonid= 277626\&type $=1$ [Accessed on 6.11.2020] 